\title{
On the Initiation Theme in The Adventures of Huckleberry Finn ${ }^{*}$
}

\author{
Liu Xi, Zhang Li-li \\ Changchun University, Changchun, China
}

\begin{abstract}
The Adventures of Huckleberry Finn by Mark Twain (1835-1910) is undoubtedly qualified as a contender for the title of the Great American Novel. It is probably the most frequently printed and widely translated in American literary history. Huckleberry himself has passed into folk knowledge and stands as a living literary legend alongside such universal figures as Falstaff, Hamlet, and Don Quixote. The present paper gives a brief introduction of the story and the initiation theme. Then, it mainly explores the initiation theme from three aspects: the plot pattern, the main characters, and the change of Huck's attitudes towards social culture.
\end{abstract}

Keywords: initiation theme, plot pattern, social culture, major characters

\section{Introduction}

The writers all over the world attach great importance to the growth of youth in the modern literary circle. For one thing, the new generations are the nation's backbone of future, for another, growth is the eternal theme in the human society. Leslie A. Fielder, the great literary critic, said, "Nearly all the great novelists built their reputation on the works related to the youth". He also stated that "American always aspire to their childhood" (Leslie, 1987, p. 33). According to Bakhtin's (1975) (as cited in Susan, 2002, p. 89) definition, the renowned and representative initiation stories are as follows:

The Adventures of Robinson Crusoe in the 18th century; David Copperfield, Great Expectations, Jane Eyre, and The Adventures of Huckleberry Finn in the 19th century; A Portrait of the Artist as a Young Man, Sons and Lovers, The Invisible Man, The Catcher in the Rye, and The Song of Solomon in the 20th century.

Initiation theme has been elaborated by generations of writers in the Western literary history which describes the growth of a teenager by undergoing some life experiences. The great initiation stories teach young adults and teenagers how to survive in the complex environment. Those who have gone through the growth are quite aware of the meaning and significance of existence. The confusion and fear mixed with the longing and curiosity and the inexpressible shocks accompanied by the subtle physiological changes add a tint of mystery and shyness to the stage of growth. The Adventures of Huckleberry Finn is a myth about a boy, Huckleberry Finn (hereinafter refered to as Huck), who experiences initiation from adolescence into adulthood. In the story:

Mark Twain explores the process of initiation deeply by portraying an image of a boy adventurer, Huckleberry Finn, who chafed under the bonds of civilization and escaped his boring world and his selfish father by sailing a raft down the Mississippi River. (Louis, 1987, p. 52)

\footnotetext{
* This paper is a part of the result of the research program "The Study of Counter-Elite Essentiality in American Post-modernism Novels" (2013, No. 265), in which the authors have participated.

Liu Xi, M.A., lecturer, School of Foreign Languages, Changchun University.

Zhang Li-li, M.A., lecturer, School of Foreign Languages, Changchun University.
} 
Huck's friend Jim, a slave who run away from being sold, was accompanying him. The two boys struck a bond of friendship that took them through melancholy events and exalted adventures. Huck sets up a good example for the illustration of initiation theme by his unusual experiences. The paper discusses the initiation theme from the perspectives of the plot pattern, the main characters, and the change of Huck's attitudes towards social culture to show the process of growth and maturity of Huck.

\section{Initiation Theme Reflected in the Plot Pattern}

Through the lively experience of a teenager's initiation, Mark Twain illustrated the universal growth from innocence to experience and the ordeals in between. Like many other American writers of initiation stories, Twain drew inspiration from the traditional culture and imparted new meaning to the eternal motif of initiation. As an independent subgenre, the American initiation stories, to a great extent, rely on the archetypal plot pattern of "lure-escape-confusion-epiphany" (Hutchinson, 1993, p. 102). The archetypal progression as well makes contributions to evoking the collective unconsciousness of the readers all over the world, which accounts for its worldwide popularity.

Almost all the protagonists in the initiation stories have the character of transforming from innocence to maturity. The key of experience is innocent lure which gives an impetus to protagonist's initiation. In The Adventures of Huckleberry Finn, incentive refers to the lure of the outside world. Just like other teenage boys, what Huck wanted was freedom and unrestricted life. The reason why Huck escaped from the family by being attracted by the outside was that both his family and the adopt family failed to provide him with proper social acknowledgement and love that he greatly needed in his boyhood.

In the kin family, Huck only had a father who was drunk all the time and paid no attention to him. As a rough tramp and an uncontrolled alcoholic, his father, Pap Finn, could not naturally fulfill his role as a tender parent who was expected to give his due care and guidance to Huck during the critical and sensitive stage in his life. What was worse was that Pap Finn even brutally locked Huck up just because of the fortune. The pressure of the threatening physical safety directly attracted Huck into his Odyssey along the Mississippi River. The role his father played in Huck's life was an important incentive that made Huck escape from his family.

For another, the adopted family had little positive influence on Huck's life, for it was a broken home. The family members, Miss Watson and widow Douglas, were impatient with Huck's need and caring nothing about Huck so that he felt lost and lonely and he even said that he wished he were dead. That was the second incentive that made Huck escape from the adult world.

The third incentive was Huck himself. He was just like a seed, never watered by "adults rules". He did not go to church, he loathed religious education and never made prays. It was nature that made him run away from the society he lived so as to establish deep friendship with Jim.

Escape is a necessary stage for all protagonists in the American initiation novels. They break the social rules not for a livelihood, but for real meaning of life. Actually, they are spiritual explorers. Huck is typical initiation protagonist in American literature. The traditional civilization and religious preaching make him escape. "I got into my old rags and my sugar hogshead again and was free and satisfied" (Mark, 1994, p. 35). Huck not only escaped from his relatives, but also from the society. For him, the raft, the Mississippi River, and nature represented freedom that he dreamed of for long. Only on the raft along the river with Jim did he feel comfortable and quiet. 
Confusion is the third stage of initiation. In the process of growing up, Huck came to discover rudeness and ridiculousness of his father. He felt that widow Douglas and Miss Watson were boring and stubborn as well, thus, he escaped. After he started his journey with Jim, he witnessed men and incidents that he never experienced before, he confused about everything he underwent.

"In initiation stories, the protagonists often feel increasingly confused about the world. They acquired initiation and maturity through the awareness and solution to the confusion" (Louis, 1985, p. 73). With the journey down the Mississippi River, Huck and Jim came to establish reliable friendship. Jim, a black guy, was not only Huck's companion, but an intimate friend. Huck found his heaven in the little raft with Jim, for he had witnessed much of the ridiculous and hypocritical society: the murderous treatment of Jim Turner on Walter Scott streaming boat, the killing of Buck Grangerford that still disturbed his sleep, etc.. Throughout the adventure, for Huck, the journey with Jim was a process of moral growth and inner awakening. He finally arrived at the stage of epiphany, because he was waken by social evils.

As a white boy growing up in the society where slavery was widely prevailing, Huck had the traditional thought that the blacks were born to be slaves and inferior to the whites. He thought that slavery was proper in which the white was bound to tell on any runaway slave. If there were anyone who helped niggers to escape, they would "go to hell". Yet, Huck gradually threw these traditional prejudices away like rubbish during his journal of adventure, he finally broke the social rules and advocated equality democracy. Huck discovered his nature and found his spiritual awakening and character sublimation.

\section{Exploration of Social Culture in the Initiation Theme}

No matter how it is defined, culture can be considered omnipresent. People begin to be influenced by the culture of the place where they are since they were born. The situation one faces is largely the result of previous behavior of the members of the same or different society, so he/she cannot avoid the cultural influence. In the meanwhile, literature is the mirror of culture, that is, culture of a country can be obviously reflected in the literary works of various forms. "In this novel, the author sets the story in the cultural atmosphere of the society in the South of America in the 1840s, the cultural background provides the novel with profound connotation" (Bradley \& Cooley, 1997, p. 298). The specific social culture at that time undoubtedly had a great influence upon the growth of Huck.

It is self-evident that Huck's understanding of the world before and after the adventure was different. Before he run away from the civilized world, Huck had lived in pre-civil war period in the 1840s before the adventure in the wilderness. At that time, the prevailing social culture was an obvious prejudice and distain against black slaves. As a child, before he took the adventure, Huck simply adopted the opinion that blacks were born to be salves and they were inferior to whites. In his adventure, especially he made friends with the black boy, Jim, Huck gradually began to change his attitudes towards slaves and slavery, so as to make him being mature mentally.

Jim, an image of a kind and innocent black boy, was created by Mark Twain with much profound significance because Twain himself was anti-slavery severely. Huck was born into a white family so that naturally he thought black people were born to be inferior to whites before the adventure, because Huck lived in his own isolated world like adult whites whose mind was fully occupied by the "legal" slavery. He had no opportunity or possibility to evaluate or doubt the unreasonable part of slavery.

Huck and Jim got closer in the adventure, and then Huck knew Jim better. He found that though Jim was a 
slave, he was sincere, kind, and disinterested. At that time, Huck realized the two sides of his heart: a natural one and a civilized one. From the natural side of the heart, Huck found that Jim was not different from whites both physically and spiritually so that he felt Jim was exactly like him. He also felt that the treatment to the black people was truly unjustified. On the other hand, as a "civilized" person, he was largely restricted by the culture in the American society, and the restriction derived not only from the outside world, but also from the inside world which existed as cultural factors in the personal unconsciousness and an individual regarded it as an instinctive need. The humanity was contradictory to the civilized society. Then, Huck had to face both the restriction from the outer society and the trial of his own soul. Under such circumstances, Huck was in a panic constantly. He found that it was a "crime" to help Jim and "people that acts as I'd been acting about the nigger goes to everlasting fire" (Mark, 1994, p. 55) because "My wickedness wad being watched all the time from up there in heaven" (Mark, 1994, p. 86). Consequently, he prepared a piece of paper and a pencil, and wrote a letter to Jim's owner, Miss Watson, so as to feel relieved.

In the first bout between natural Huck and cultural Huck, the cultural one won. If Huck stopped his pace to pursue mental growth, he would be just the same as all the other ordinary whites who are obedient to the traditional cultural restriction. However, Huck discovered his nature through the adventure with Jim. Finally, Huck tore the letter into pieces and began to face the great mental change. The natural Huck defeated the cultural one. Huck's actions showed the oppression of the southern culture to humanity. His contradiction and affliction finally escaped from him, which symbolized his initiation under the cultural oppression, and the cost of rebelling against the traditional social culture.

\section{Exploration of Major Characters in the Initiation Theme}

Apart from analyzing the plot pattern of the story, and the change of Huck's attitudes towards social culture in initiation, the initiation theme of the novel is also revealed by the main characters and the influence of other characters upon main characters.

Firstly, Huck was a typical character in American initiation stories: both lovely and naughty, and with childlike innocence and unpretending goodness behind the appearance of a vagabond. There were different difficulties and troubles in the course of growing up. There are many narrations reflected Huck's personality anywhere in the story. Those narrations describe a typical "American boy" and reflect puzzlements in the growing up of adolescents: (a) his refusal of "civilization" and his desire for freedom; (b) his dissatisfaction with the up-to-date life and environment and his eagerness for escape and exploration; and (c) pragmatic principles, according to nature theorem of justice and interest. However, his inherent feeling of justice caused him to be able to treat the black slave fairly, and to know to be grateful and protective to his friend.

In addition to the hero, Huck, as an indispensable structural element, "There is also a guide for the hero's growth in the structure of an initiation story, which is also a very important element" (Louis, 1985, p. 67). Everyone's initiation must be influenced by others who can enhance the life experience of the hero and cognition of society in positive and negative aspects. The adolescents gradually establish their own roles and make them know about the meaning of life. In The Adventures of Huckleberry Finn, the guide was Jim, a kindly, warm-hearted black boy. As for Huck, Jim was like a father and friend who gave him courage and bravery. The other day, Jim wanted to reach Cairo, a free state, by taking a steamboat upriver where Jim would finally be a free man. While they were approaching that part of the river, they encountered a heavy fog which made them separated. Huck was thrown in a strong panic while he found no trace of Jim. He was searching for 
him for a long time and during the process of search, he began to realize that Jim was an important role in his life though Jim was a black, because Jim cared him a lot and taught him a lot as well. What is more, Jim was honest, tolerant, and sympathetic. He taught Huck what friendship was and what virtue was. He made Huck understand what faithfulness was and taught him how to conquer the social morality with the natural morality. He also instructed Huck how to establish his own moral consciousness and even social justice. It was Jim who gave him sincere instructions to help him grow up and being mature.

\section{Conclusion}

People have begun to pay attention to growth of young adults with the development of industrialization and urbanization. "Sebald thinks the appearance of young adults is a product of industrial society" (Louis, 1987, p. 39). Industrial society demands its citizens to have high technology and organization and law consciousness, so children need a long time to study and grow. It is a serious challenge for children to melt into the complex and conflicts-filled society. On one hand, young adults hope to get great room to develop themselves independently and freely. On the other hand, they have to rely on the care and guidance of adults. They stay in a dilemma that they dream of growth but are afraid of growth and they yearn to choose independently but worry about results. In the 1940s, the study on the initiation theme in literary works sprung up in America. Initiation novels probe into the psychological world of young adults and make use of the power of the purification of art to guide them how to face troubles and frustration in life and how to form an optimistic world outlook and life viewpoint. The Adventures of Huckleberry Finn is generally acknowledged as a classic initiation story in American literature. The adventure experiences show the growth and maturity of Huck. The story well fits the basic structure of initiation theme novels: the typical plot pattern of temptation-leaving-ordeals-epiphany, and the change of attitudes towards the social culture after undergoing something unusual in the journey of adventure. In this sense, Mark Twain can be viewed as a great author who can control the initiation theme skillfully.

\section{References}

Bradley, S. L., \& Cooley, T. (1997). Adventures of Huckleberry Finn: An authoritative text, backgrounds and sources criticism (2nd ed.). New York, N.Y.: W. W. Norton \& Company.

Gui, Y. Q. (1985). Selected reading in English and American literature. Beijing: Translation Company Press.

Hutchinson, S. (1993). Mark Twain: Critical assessments. New York, N.Y.: Routledge Information Ltd..

Leslie, A. F.(1987). End to innocence. Boston, M.A.: Beacon Press.

Louis, J. B. (1985). New essays on Adventures of Huckleberry Finn. Cambridge, U.K.: Cambridge University Press.

Louis, J. B. (1987) On Mark Twain. Durham, U.K.: Duke Univertisy Press.

Mark, T. (1994). The Adventures of Huckleberry Finn. Guangdong: Gospel Light Publications.

Michael, P. (1996). A dictionary of cultural and critical theory. Oxford, U.K.: Blackwell Publishers Ltd..

Raman, S., \& Peter, W. (2004). A reader's guide to contemporary literary theory. Beijing: Foreign Languages Press.

Susan, C. (2002). Mark Twain's escape from time. London, U.K.: University of Missouri Press.

Wilfred, L. G. (2004). A handbook of critical approaches to literature. Beijing: Foreign Language Teaching and Research Press. Zhang, S. Y. (2005). History of Western literature in 20th century. Beijing: Peking University Press. 